STUDIA PRAWNO-EKONOMICZNE, T. CVI, 2018

PL ISSN 0081-6841; $\quad$ e-ISSN 2450-8179 $\quad$ s. 265-278

https://doi.org/10.26485/SPE/2018/106/16

\title{
THE EUROPEAN UNION BUDGET AS AN INDICATOR OF CHANGES IN EU POLICIES
}

\begin{abstract}
(Summary)
The focus of this paper is on the EU budget and the changes in European policies. The basic objective of the paper is to assess how the political priorities of the European Union are reflected in the EU budget, mainly on the expenditure side. Questions about the purpose of the budget and the principles that govern the use of public finances in the Union are linked to wider questions about the nature of the EU and its evolution. The paper contributes to the theoretical debates on European policy and public finances, but also provides policy insights on the relationship between the EU policy process and the budget.

The development of budgetary expenditures follows the development of EU policies. Hence this paper detects the interrelationships among the policies of the Union; all policy areas interact with one another, which is particularly visible in EU budget. Many areas of EU policy are regulatory in nature and have few requirements for spending, except for administration. The EU has a significant responsibility in relation to only one area important to public expenditure: economic affairs. However, EU spending programmes pursue a multiplicity of grand objectives, often unrelated to the available funding. The relatively small size of the EU budget makes the EU's rules (the regulatory sphere) matter more than the EU's expenditures in attaining political priorities.
\end{abstract}

Keywords: European Union; EU budget; European public policy

JEL classification: E61, E62, F36

\section{Introduction}

The focus of this paper is on the EU budget and the changes in European policies. The basic objective of the paper is to assess how the political priorities of the European Union are reflected in the EU budget, mainly on the expenditure side.

* PhD, Pedagogical University of Cracow, Department of Economics and Economic Policy; e-mail: dorota.murzyn@up.krakow.pl 
Questions about the purpose of the budget and the principles that govern the use of public finances in the Union are linked to wider questions about the nature of the EU and its evolution. The paper contributes to the theoretical debates on European policy and public finances, but also provides policy insights on the relationship between the EU policy process and the budget.

One of the major problems in studying policy reforms is how to measure the magnitude of policy changes. It is certainly possible to make qualitative evaluations of policy changes by comparing pieces of legislation before and after the change (for example by using the European Commission's online databases Lex and PreLex). What is much more challenging is how to measure the extent to which a policy has changed. The use of budgetary data is the main strategy adopted in the literature for dealing with this problem.

This paper reviews the main literature, with particular reference to the debates surrounding public policy analysis and public finance, and develops an analytical framework from the literature concerning policy and institutional changes. This framework is then applied to the European Union budget. The desk research involves analysis of the primary sources, such as policy documents and legislation. The empirical analysis is based on tracking the evolution of macro areas of expenditure and uses some intervening variables, such as budget growth and size.

\section{European Union policy and budget}

Public policy content is influenced by values and ideology, and its development and implementation in the EU is driven by a complex and ever-changing balance between the EU institutions, state and local governments, interest groups, independent agencies, public opinion, the media, and the international policy environment ${ }^{1}$.

The policy-making process is commonly presented as a "policy cycle". The concept of the policy cycle is a useful way of examining the processes that result in the emergence and creation of public policies. A policy cycle is made up of policy stages, which have an inbuilt sequential order to them. However, some analysts identify more stages than others ${ }^{2}$. Even though the EU is highly distinc-

J. McCormick, European Union politics, Second edition, Palgrave, London 2015, p. 294.

W. Jann, K. Wegrich, Theories of the policy cycle, in: F. Fischer, G.J. Miller (Eds.), Handbook of Public Policy Analysis: Theory, Politics, and Methods, CRC Press, Taylor \& Francis Group, Boca Raton, FL 2007, pp. 43-62. 
tive political system, the policy cycle is as much a feature of its policy processes as it is of the "normal" political systems ${ }^{3}$. A simple example of the EU policy cycle is presented at Figure 1. In the process of policy making in the European Union, priorities are changed into goals, then goals into actions, and findings from the evaluation are changed into recommendations. Budgetary issues actually appear at every stage.

FIGURE 1: European Union policy cycle

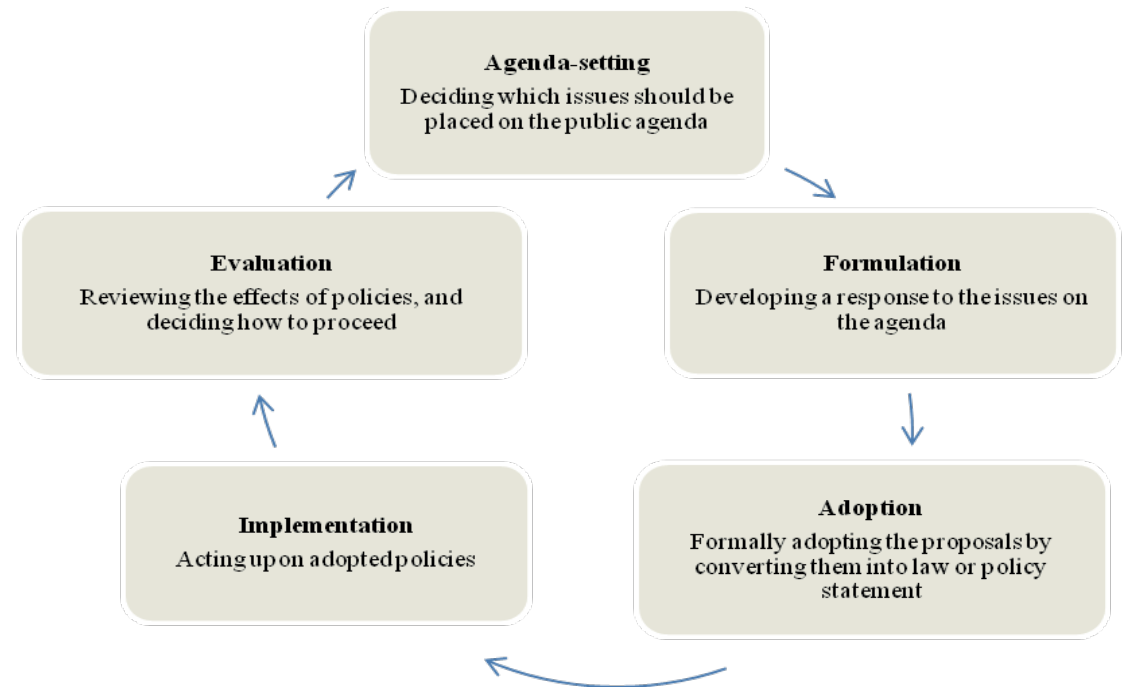

S o u r c e: J. McCormick, European Union politics, London 2015, p. 296.

There are few influences on the public policy process as important as the budget. Most government actions cost money, and the impact of policies will often depend on where funds are raised on one hand, and on the other on where the funds are spent, the efficiency of spending, and the relative amounts spent on different activities. In the EU context, formulation and passage of the budget is an extremely important act. It is something comparable to a 'yearly contract' between the Commission, the Parliament and the Council, establishing the general level of expenditure of the EU, as well as the appropriations for all the individual programmes managed by the European Commission. Any major shift in the EU budget must reflect a shared inter-institutional understanding of the changing

3 L. Buonanno, N. Nugent, Policies and policy processes of the European Union, Palgrave Macmillan, Basingstoke, Hampshire 2013. 
priorities for the EU, both in the short- as well as in the medium-term. The EU budget is a window on the EU as a political and economic institution ${ }^{4}$. The political context is of particular importance to its economic understanding 5 .

FIGURE 2: The evolution of the general budget of the European Communities / European Union in 1968-2015 (appropriations for payments, 1968-1978 in mln EUA, 1979-1998 in mln ECU, since 1999 in $\mathrm{mln}$ EUR)

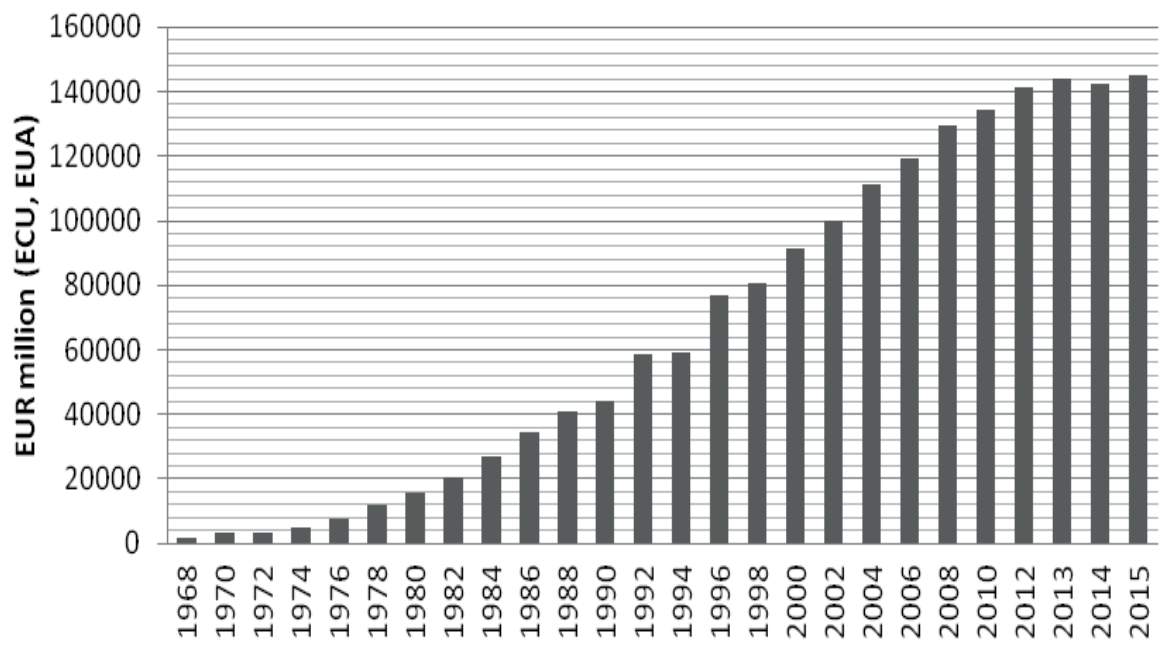

EUR million

S o u r c e: own elaboration based on European Commission, EU budget 2008, Financial report, Luxembourg: Publications Office of the European Union, 2009, Annex 2 Expenditure 1958-2008 by heading; European Commission, EU budget 2013, Financial Report, Also covering Multiannual Financial Framework 2007-13, Publications Office of the European Union, Luxembourg 2014, Annex 1 Financial frameworks 2000-06 and 2007-13; EU expenditure and revenue 2000-2015 data download from http://ec.europa.eu/budget/financialreport/2015; accessed on 30.08.2016.

The financial management of the European Union is carried out within the framework of the EU general budget and extra-budgetary funds including, among others, the European Development Fund, the European Solidarity Fund, and loans from the European Investment Bank. The effectiveness of an organization depends on its financial capacity. For many years, there have been

4 A.M. El-Agraa (ed.), The European Union: economics and policies, Cambridge University Press, Cambridge 2011, p. 289.

5 M. Artis, F. Nixson (eds.), The economics of the European Union: policy and analysis, Oxford University Press, Oxford, New York 2007. 
the increasing divergences between Member States' rising expectations and the financial capabilities of the EU. The EU has extended the range of Community policies, and financial support has included new social groups, regions or sectors of the economy, thereby increasing the burden on Member States. Throughout the whole history of the Community, the general budget funds have grown rapidly (Figure 2). The dynamic growth in income (and expenditures) was caused not only by a real increase in their value, relating largely to the process of enlargement of the Union, but also by inflation, which was quite high in the EEC countries in the 1970s and 1980s.

A causality link between the Union's competences on the one hand, and the objectives to be attained and the financial means necessary to attain these objectives on the other, was established in the Treaties. Article 3(6) of the Treaty on European Union (TEU) reads that: "The Union shall pursue its objectives by appropriate means commensurate with the competences which are conferred upon it in the Treaties" ". In turn, in the Treaty on the functioning of the European Union (TFEU) we can read that: "The Union shall provide itself with the means necessary to attain its objectives and carry through its policies" $"$. That means that the fundamental purpose of the budget is to finance Union policies. The Treaties further specify that in areas that do not fall within its exclusive competence, the Union's action is restricted to objectives that Member States cannot sufficiently achieve by themselves, in instances wherein management at the EU level would be the most cost-effective way (Art. 5(3) TEU). This is the principle of subsidiarity.

As for any EU action in accordance with the principle of subsidiarity, the EU budget's aim should be to do things that the Member States cannot (or will not) do, with better results. It is about achieving objectives of common European interest, which is more than simply transferring money across the Member States. This leads to the concept of EU added-value, which has three main characteristics: catalytic (making something happen that would otherwise not happen or happen more slowly); targeted (concentrating on the best added-value and most effective results on the basis of evaluation and impact assessment); and realistic (drawing from J. Monnet's 'balance-sheet of needs and resources') ${ }^{8}$. Another

${ }^{6}$ Consolidated version of the Treaty on European Union, Official Journal of the European Union C 202, 7 June 2016.

7 Consolidated version of the Treaty on the functioning of the European Union, Official Journal of the European Union C 202, 7 June 2016, Art. 311.

8 G. Cipriani, The EU budget: responsibility without accountability?, Centre For European Policy Studies, Brussels 2010, pp. iii-iv. 
principle of particular importance for the EU budget is the principle of solidarity. The principle of solidarity is, in the context of budget, a kind of international or intergovernmental solidarity between the Member States, and the European budget is seen as a symbol of this solidarity and an instrument for strengthening cohesion inside the EU through financial redistribution from richer to poorer Member States. However, a number of concepts of European added-value have been offered by the academic literature, and the understanding of the term "solidarity" is also different, which leads to numerous controversies. Thus, the definition of the principle of European added-value, principle of solidarity, and the use of European funds remain a political decision'. Moreover, Fabbrini reveals that the EU is nowadays characterized by a high degree of centralization in budgetary affairs, a high level of judicialization of economic questions, and a growing imbalance between the Member States in the governance of fiscal matters ${ }^{10}$.

FIGURE 3: EU budget 2016 (million EUR)

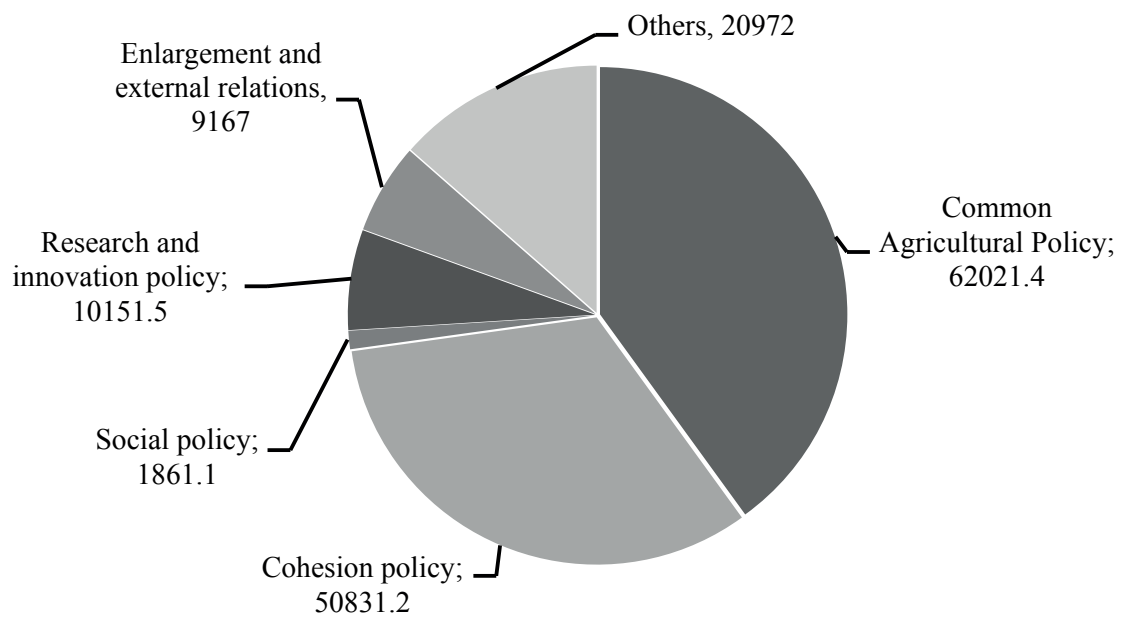

S o u r c e: European Commission, http://ec.europa.eu/budget/annual/index_en.cfm?year=2016; accessed on 30.09.2016.

9 P. Becker, The European Budget and the Principles of Solidarity and Added Value, The International Spectator, 47:3/2012, pp. 116-129.

10 F. Fabbrini, Economic governance in Europe: comparative paradoxes, constitutional challenges, Oxford University Press, Oxford 2016. 
Many areas of EU policy are regulatory in nature and contain few requirements for spending, leaving little or no footprint on the budget. The EU has significant responsibility in relation to only one area important to public expenditure - economic affairs. European integration has long focused on economic matters. Economic policy is routinely at the top of the public policy agenda in every free-market system. However, while market integration remains, in principle, a core mission of the EU, that integration must now be pursued in a manner consistent with improving gender equality and achieving a high level of social and environmental protection ${ }^{11}$.

When we look at the EU budget (Figure 3 above), we can observe that the most funds go to the distributive policies that aim to sustain specific economic sectors (e.g. the Common Agricultural Policy), or redistribute unbalanced resources for the purpose of promoting social and economic cohesion (the cohesion policy). EU policies based on the distribution of budgetary resources constitute, if treated in aggregate, a significant sample of policies decided at the EU level, and their analysis contributes substantially to our understanding of the policy dynamics of the EU.

\section{The evolution of EU expenditures}

Leaving aside the analysis of changes on the revenue side of the EU budget, let us look at the evolution of the main categories of expenditure of the EU. The study performed in this paper is based on the statistical data of the European Commission from the EU budget Financial Reports and the information published on the Commission's official website. It constitutes comprehensive study on the evolution of the EU budget from 1960 until nowadays. All the budgetary figures are expressed in relative rather than absolute terms, i.e., as a percentage of the general budget. This makes it possible to control three 'disturbing' factors, all of which could strongly bias the data: the effect of inflation, the effect of changeover from the European Unit of Account (EUA) and European Currency Unit (ECU) to the euro (EUR); and the budgetary growth stemming from the process of enlargement of the EU, which increased the general level of resources of the EU.

Compared to 1960, when the entire EEC budget was intended only for administrative expenses, today's EU budget structure is very diverse. As we can

11 M. Carson, M., T.R. Burns, D. Calvo (eds.), Paradigms in public policy: theory and practice of paradigm shifts in the EU, Peter Lang, Frankfurt am Main, New York 2009, p. 411. 
see on the graph (Figure 4), and as it is widely known, the size of the Common Agricultural Policy is quite striking, as is the constant reduction in its expenditures since 1985, when it reached a remarkable level of nearly 70 per cent of the budget. What is also noticeable is a constant increase in the relative size of the cohesion policy, with visible accelerations after the three enlargement rounds of 1986, 1995, and 2004. As the empirical evidence shows, the accession of the so-called 'cohesion countries' has produced some of the most extensive budgetary changes in the recent decades.

FIGURE 4: The evolution of the main areas of expenditures in EU budget (1960-2015)

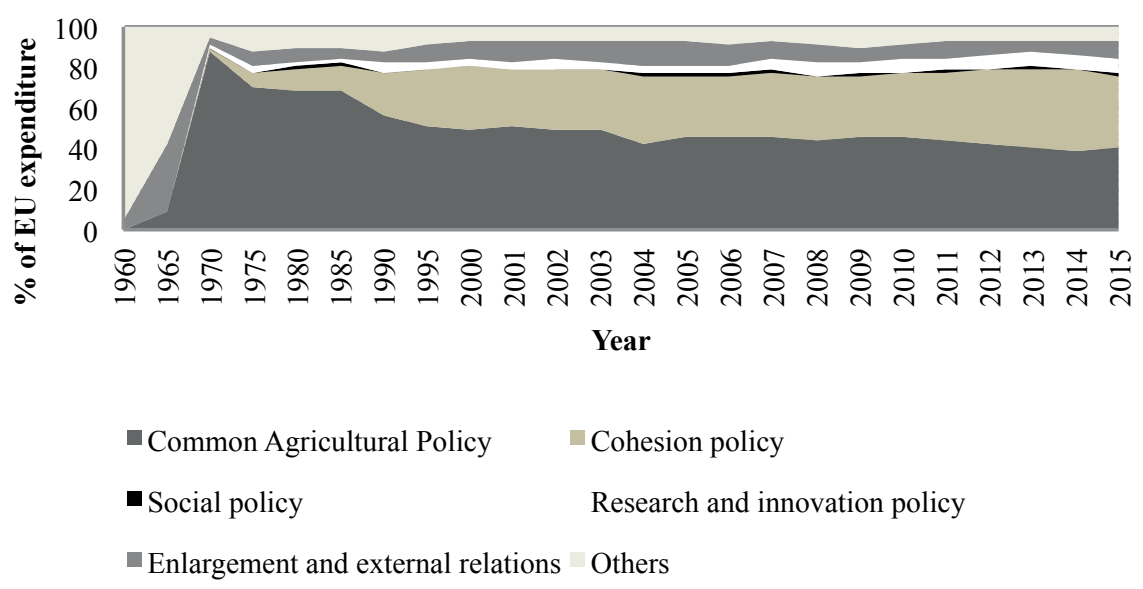

S o u r c e: own elaboration based on financial reports of the European Commission, http://ec.europa.eu/budget/biblio/documents/index_en.cfm; accessed on 30.09.2016.

These two fundamental priorities in European integration, in terms of expenditure items, i.e. the agricultural policy (guarantee) and cohesion, have been also detected applying the Principal Component Factor Analysis, which was done by Eduardo Cuenca García and José Antonio Rodríguez Martín ${ }^{12}$. This analysis reflects the application of the functionalist method of integration in Europe propounded by Monnet, with a decision-making procedure in matters that would not prejudice the fundamental interests of any of the countries, as opposed to the federal model, which promotes the political unification of the

12 E. Cuenca García, J.A. Rodríguez Martín, Evolution of Expenditure in the Budget of the European Union (1957-2002), European Planning Studies, 15:8/2007, pp. 1113-1126. 
continent via broad transfers of sovereignty from the countries to the community institutions.

Another interesting research was carried out by Manuele Citi ${ }^{13}$, who studied the long-term evolution of the main categories of expenditures of the European Union budget (1984-2011). The aim was to assess the extent to which the EU is affected by a structural form of policy inertia, and to investigate the general pattern of policy stability and change in the EU in light of the two models of policy dynamics currently existing in the literature: the incrementalist model and the punctuated equilibrium model. The analysis of long series of original data extracted from the EU budget showed that EU policies do not evolve following an incrementalist pattern, but by a punctuated equilibrium dynamic.

The dominance of agricultural subsidies and regional development expenditures during the history of the European Union's budget clearly indicates that the primary aim of Member States with regard to the EU budget is to use it for redistributive purposes rather than for promoting the achievement of other common objectives of the Union. The presently concluded Multiannual Financial Framework 2007-2013 and the ongoing one for 2014-2020 have introduced some changes to the way the funds are programmed in EU Member States and regions. Earmarking and integrated planning are designed to transform the EU budgetary support from sectoral and cohesion-oriented transfers to a powerful EU policy implementation tool ${ }^{14}$. With Europe 2020, the EU budget has become fundamental in motivating regions and Member States to focus on the Europe 2020 flagship objectives. The new headings clearly indicate which issues and objectives need to be funded through the EU budget to meet the strategic objectives of the Union. The CAP is no longer the largest expenditure heading; instead interventions to improve competitiveness are at the top of the budgetary lines.

However, despite the new budgetary headings, it can be concluded that the budgetary frameworks do not represent a radically new expenditure structure. When we compare the last three financial perspectives (those involving Poland), we can notice that these budgets are fundamentally characterized by a continuation of the "historically developed" expenditure structure, with only minor changes in proportions (Figure 5). The agricultural policy, which is almost universally regarded as extremely costly, has been allocated the most

13 M. Citi, EU budgetary dynamics: incremental or punctuated equilibrium?, Journal of European Public Policy 2013/20:8, pp. 1157-1173.

14 J. Núñez Ferrer, M. Katarivas, What are the effects of the EU budget: Driving force or drop in the ocean?, CEPS Special Report, No. 86, Centre For European Policy Studies, Brussels 2014. 
funds, although the expenditures for it are gradually decreasing. Partly as a result of this approach, the main instruments for strengthening the competitiveness of the European economy (e.g. through R\&D and educational programmes) have not been allocated significantly higher shares in the budget, although some serious shifts have begun that could increase the budgetary allocations for these policies.

FIGURE 5: Comparing 2000-2006, 2007-2013 and 2014-2020 MFF (Multiannual Financial Frameworks) commitment appropriations

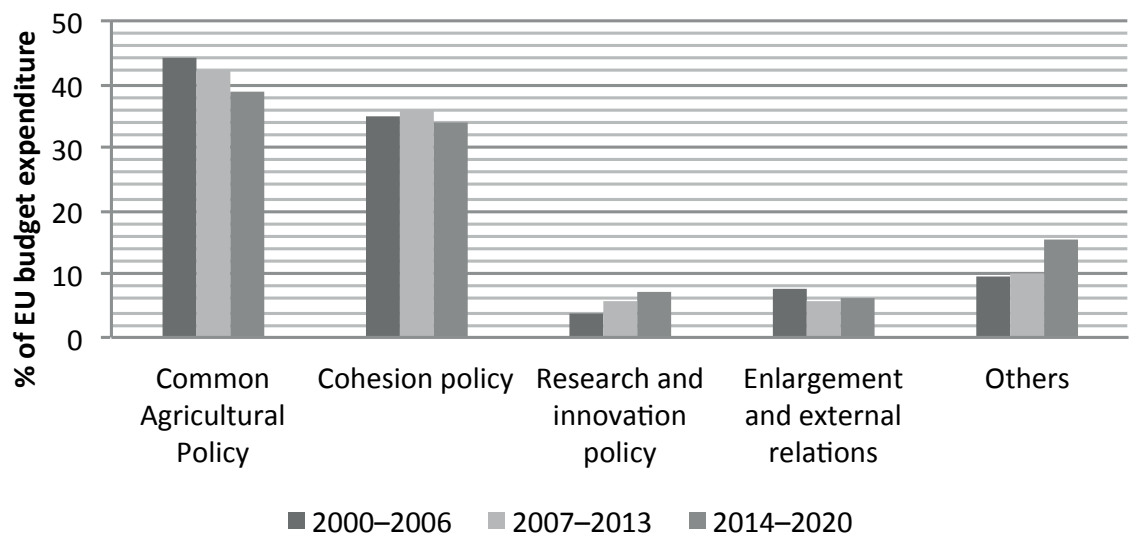

S o u r c e: own elaboration based on data of European Commission, http://ec.europa.eu/budget/ biblio/documents/index_en.cfm; accessed on 30.09.2016.

Due to the "rigidity" of the EU budget, more important changes, in financial terms, seem to occur in the two major policies. Both the cohesion policy and the agricultural policy (albeit to a lesser extent) are increasingly focusing on the issues of innovation or the environment, that are at the top of EU policy agenda now. The research and innovation policy and environmental policy also appears both directly and indirectly in the EU budget expenditures. Compared to one another, the direct expenditures for research and innovation policy are much larger than the direct sources of environmental policy in the framework of the "Sustainable growth: natural resources" budgetary heading (Life programme). Nevertheless, the indirect expenditures of both policies are more considerable; however they are difficult to quantify. For example, when we look closely at the cohesion policy, we can notice a clear and growing tendency towards supporting innovation. The European Commission estimates that 
in the period 2000-2006, 29.5 billion from the structural funds $(15 \%$ of the total budget of the cohesion policy) was spent on research, technological development and innovation, while in 2007-2013 it was already approx. 86.4 billion (almost $25 \%$ of the total budget). This commitment is further strengthened in the new 2014-2020 programming period, where 30\% of the total allocations are going to be deployed for innovation in the wider sense. The European Regional Development Fund, the main instrument of the cohesion policy, is subject to "thematic concentration", focusing its investments on several key priority areas: research and innovation, the digital agenda, support for SMEs, and the low-carbon economy. In more developed regions, at least $80 \%$ of funds must focus on at least two of these priorities, while in the less developed regions this same focus covers $50 \%$ of the funds.

The analysis detected the interrelationships among the policies of the Union; all policy areas interact with one another, and this is particularly visible in EU budget. The objectives of the research and innovation policy are reflected in the cohesion and agricultural policies, while at the same time part of the R\&D policy is directed to research in the field of agriculture. The environmental goals are implemented both under the cohesion and agricultural policies as well. The social policy objectives are executed by the cohesion policy spending. These interactions make the analysis of policy changes in the European Union by using the budgetary figures more challenging.

It should be emphasized that the size of the EU budget is rather modest: the expenditures make up less than one per cent of the EU's gross national income (GNI) (see: Figure 2). The relatively small size of the EU budget makes the EU's rules (i.e. the regulatory sphere) matter more than the EU's expenditures aimed at attaining political priorities ${ }^{15}$. However, the EU budget has the potential to influence the European economy much more than its modest size in terms of GNI may suggest. There is an increasing role on the part of the financial instruments, which are fundamentally changing the budget's nature and reach ${ }^{16}$. Through these instruments, the EU can invest more efficiently in more areas and mobilize a multiplicity of funds. The introduction of financial instruments which combine EU budgetary support with loans by the EIB Group (European Investment Bank and European Investment Fund), as well as from other financial institutions, is seen as one way of expanding

5 J. Núñez Ferrer, Investing where it matters: an EU budget for long-term growth, CEPS Task Force Report, CEPS, Brussels 2012.

16 J. Núñez Ferrer, M. Katarivas, What are the effects of the EU budget: Driving force or drop in the ocean?, CEPS Special Report, No. 86, Centre For European Policy Studies, Brussels 2014. 
the reach of the EU budget and increasing its effectiveness. A similar situation is taking place with respect to national co-financing, which also increases the EU budget possibilities and can be a guarantee for effective spending as opposed to the simple absorption of funds, since Member States will naturally try to avoid wasting their own funds. Reforming the EU budget to make it more supportive of economic growth is important as well, although it will not substantially affect overall growth in the Union because of its small dimension ${ }^{17}$. The budget can however add significant leverage effects, which will encourage growth in the overall economy.

\section{Conclusions}

The development of budgetary expenditures follows the development of EU policies, although not always in a direct way, and some changes may only be slightly reflected in the budget's structure. As enlargement increased the EU's heterogeneity, it was deemed necessary to introduce a greater redistributive element into the budget by expanding and concentrating expenditures on structural operations. Expenditures on research have increased as a result of concerns over EU competitiveness. However, EU spending programmes pursue a multiplicity of grand objectives, often unrelated to the available funding.

In its present form, the EU budget can be considered as a historical relic. Expenditures, revenues, and budgetary procedures are all inconsistent with the challenges of EU integration. If the Union is determined to pursue ambitious goals and respond to existing challenges, the EU budgetary structure should move away from its present inertia, which allows for only minor experimentation, and be radically restructured. Giving the highest priority to growth implies that a larger share of the EU budget should be transferred to growth-enhancing projects, such as R\&D and innovation. However, significant changes in the distributive order of the Union seem unlikely because of a strong status-quo bias in EU budgetary politics, in terms of both institutional structures and the preferences of the major actors. This creates a certain discrepancy between the expenditure priorities of the EU budget and key policy priorities facing Europe.

17 A. Mayhew, Reforming the EU budget to support economic growth, SEI Working Paper No. 128, Sussex European Institute 2012. 


\section{References}

Artis Mike, Nixson Frederick (eds.), The economics of the European Union: policy and analysis, Oxford University Press, Oxford, New York 2007.

Becker Peter, The European Budget and the Principles of Solidarity and Added Value, The International Spectator 2012/47:3, pp. 116-129, DOI: 10.1080/03932729.2011.628105.

Buonanno Laurie, Nugent Neill, Policies and policy processes of the European Union, Palgrave Macmillan, Basingstoke, Hampshire 2013.

Carson Marcus, Burns Tom R., Calvo Dolores (eds.), Paradigms in public policy: theory and practice of paradigm shifts in the EU, Peter Lang, Frankfurt am Main, New York 2009.

Cipriani Gabrielle, The EU budget: responsibility without accountability?, Centre For European Policy Studies, Brussels 2010.

Cipriani Gabrielle, Financing the EU budget: moving forward or backwards?, Rowman \& Littlefield International, Ltd., London; Centre For European Policy Studies, Brussels 2014.

Citi Manuele, EU budgetary dynamics: incremental or punctuated equilibrium?, Journal of European Public Policy 2013/20:8, pp. 1157-1173, DOI: 10.1080/13501763.2012.760333.

Citi Manuele, European Union budget politics: Explaining stability and change in spending allocations, European Union Politics 2015/16 (2), pp. 262-280, DOI: 10.1177/1465116515569551.

Consolidated version of the Treaty on European Union, Official Journal of the European Union C 202, 7 June 2016.

Consolidated version of the Treaty on the functioning of the European Union, Official Journal of the European Union C 202, 7 June 2016.

Cuenca García Eduardo, Rodríguez Martín José Antonio, Evolution of Expenditure in the Budget of the European Union (1957-2002), European Planning Studies 2007/15:8, pp. 1113-1126, DOI: 10.1080/09654310701448279.

El-Agraa Ali M. (ed.), The European Union: economics and policies, Cambridge University Press, Cambridge 2011.

European Commission, EU budget 2008, Financial report, Publications Office of the European Union, Luxembourg 2009.

European Commission, EU budget 2013, Financial Report, Also covering Multiannual Financial Framework 2007-13, Publications Office of the European Union, Luxembourg 2014.

Fabbrini Federico, Economic governance in Europe: comparative paradoxes, constitutional challenges, Oxford University Press, Oxford 2016.

Jann Werner, Wegrich Kai, Theories of the policy cycle, in: Frank Fischer, Gerald J. Miller, Mara S. Sidney (eds.), Handbook of Public Policy Analysis: Theory, Politics, and Methods, CRC Press, Taylor \& Francis Group, Boca Raton, FL 2007, pp. 43-62.

Levy Roger, Implementing European Union public policy, Edward Elgar, Northampton, MA 2000.

Mayhew Alan, Reforming the EU budget to support economic growth, SEI Working Paper No. 128, Sussex European Institute 2012.

McCormick John, European Union politics, Second edition, Palgrave, London 2015.

Núñez Ferrer Jorge, Investing where it matters: an EU budget for long-term growth, CEPS Task Force Report, CEPS, Brussels 2012.

Núñez Ferrer Jorge, Katarivas Moni, What are the effects of the EU budget: Driving force or drop in the ocean?, CEPS Special Report, No. 86, Centre For European Policy Studies, Brussels 2014. 
Richardson Jeremy (Ed.), European Union: power and policy-making, Routledge, Abingdon [U.K.]; New York 2006.

Wallace Helen, Pollack Mark A., Young Alasdair R. (eds.), Policy-making in the European Union, Sixth edition, Oxford University Press, Oxford, New York 2010.

Dorota MURZYN

\section{BUDŻET UNII EUROPEJSKIEJ JAKO WSKAŹNIK ZMIAN POLITYK UE}

(Streszczenie)

Celem artykułu jest próba oszacowania, w jaki sposób priorytety polityczne Unii Europejskiej są odzwierciedlane w budżecie UE. Pytania na temat celów budżetu oraz zasad, które regulują wykorzystanie finansów publicznych w Unii, są powiązane z szerszymi pytaniami o charakter UE i jej ewolucję. Artykuł jest przyczynkiem do debaty na temat polityk i finansów publicznych Unii Europejskiej oraz pokazuje relacje między procesem kształtowania polityk Unii a jej budżetem.

Rozwój wydatków budżetowych następuje wraz z rozwojem polityk unijnych. Istnieje przy tym współzależność między politykami Unii; wszystkie obszary polityki współdziałają ze sobą, co jest szczególnie widoczne w budżecie UE. Wiele obszarów polityki UE ma charakter regulacyjny i małe wymagania dotyczące wydatków budżetowych, z wyjątkiem administracji. Unia Europejska posiada znaczącą odpowiedzialność tylko w stosunku do jednego obszaru istotnego dla wydatków publicznych - spraw gospodarczych. Jednakże wiele programów i funduszy UE realizuje tak wiele różnych ambitnych celów, że często są one nieadekwatne do dostępnego budżetu. Stosunkowo niewielki rozmiar budżetu UE sprawia, że przepisy i zalecenia (sfera regulacyjna) mają większe znaczenie niż wydatki budżetowe w osiąganiu priorytetów politycznych.

Słowa kluczowe: Unia Europejska; budżet ogólny UE; polityki publiczne UE 